\title{
Synthesis of Phidianidines A and B
}

\author{
Hong-Yu Lin and Barry B. Snider \\ Department of Chemistry MS 015, Brandeis University, Waltham, Massachusetts 02454-9110, \\ United States
}

Barry B. Snider: snider@brandeis.edu

\section{Abstract}

Reaction of a substituted indole-3-acetyl chloride with $N$-5-azidopentyl- $N^{\prime}$-hydroxyguanidine generated a substituted 3-(5-azidopentylamino)-5-((indol-3-yl)-methyl)-1,2,4-oxadiazole. Reduction of the azide with zinc and ammonium formate afforded the amine, which was elaborated to the guanidine, completing short and efficient syntheses of the cytotoxic natural products phidianidines A and B in $19 \%$ overall yield by a convergent route that will make analogues readily available for biological evaluation. Initial screening in the NCI 60 cell line at $10^{-5} \mathrm{M}$ indicated that the bromine on the indole is necessary for activity and that the amine precursor to phidianidine $\mathrm{A}$ is more potent than phidianidine $\mathrm{A}$.

Guo, Gavagnin, and co-workers recently reported the isolation of the guanidine-containing natural products phidianidines A (1a) and B (1) $)$ as the trifluoroacetate salts from the shellless marine opisthobranch mollusk Phidiana militaris (see Scheme 1). ${ }^{1}$ Despite their relatively simple structure, the phidianidines are of interest because they appear to be the first natural products that contain an 1,2,4-oxadiazole ring. ${ }^{2}$ Furthermore, they show significant cytotoxicity at 0.14 to $5.42 \mu \mathrm{M}$ concentrations against the highly proliferating C6 rat glioma and HeLa epithelial cervical cancer cell lines and the embryonic 3T3-L1 murine embryonic fibroblast and $\mathrm{H} 9 \mathrm{c} 2$ rat embryonic cardiac myoblast cell lines and are less toxic to the less rapidly proliferating $\mathrm{CaCo}-2$ epithelial colorectal adenocarcinoma cell line (35 to $100 \mu \mathrm{M}) .{ }^{1}$ The mode of action is not known, but the closely related dodecylguanidinium acetate $(\mathbf{4}$, dodine) has been in widespread use since 1956 as a fungicide and may act by membrane disruption. ${ }^{3}$ As part of an ongoing program in the synthesis of structurally novel guanidine-containing natural products, ${ }^{4}$ we planned to prepare phidianidines A (1a) and B (1b) by coupling of the appropriate ethyl indole-3-acetate ( $\mathbf{2 a}$ or $\mathbf{2 b}$ ) with hydroxyguanidine 3 containing a suitably protected nitrogen on the other end of the five carbon side chain. There is limited precedent for the synthesis of 3-amino-1,2,4-oxadiazoles by coupling of esters with hydroxyguanidines ${ }^{5}$ and nature may use a related route for the biosynthesis of the phidianidines.

We chose to use hydroxyguanidine $\mathbf{8}$ with an azidopentyl side chain because the azide group can be easily elaborated into the guanidine of the phidianidines and a wide variety of analogues (see Scheme 2). Furthermore, 5-azido-1-pentanamine (6) is readily available in quantity in $85 \%$ yield by selective reduction of diazide 5 by Kim's procedure with triphenylphosphine in a two-phase system. ${ }^{6 a}$ After mono-reduction of the diazide in $\mathrm{Et}_{2} \mathrm{O} / \mathrm{EtOAc}$, the azido amine is protonated and partitions into the $5 \% \mathrm{HCl}$ solution, thereby preventing

Correspondence to: Barry B. Snider, snider@brandeis .edu.

Supporting Information Available: Results from the NCI 60 cell screens of phidianidine A (1a), phidianidine B (1b), amine 12a, and amine 12b, tables of spectral data, and copies of ${ }^{1} \mathrm{H}$ and ${ }^{13} \mathrm{C}$ NMR spectral data. This material is available free of charge via the Internet at http://pubs.acs.org. 
reduction of the second azide. Reaction of amine $\mathbf{6}$ with cyanogen bromide ${ }^{7}$ in $\mathrm{CH}_{2} \mathrm{Cl}_{2}$ and aqueous $\mathrm{NaHCO}_{3}$ solution afforded somewhat unstable cyanamide 7 , which was treated with hydroxylamine hydrochloride ${ }^{8}$ and $\mathrm{K}_{2} \mathrm{CO}_{3}$ in $\mathrm{EtOH}$ to give the unstable ${ }^{8 \mathrm{~d}}$ hydroxyguanidine $\mathbf{8}$, which was used immediately for the next step.

Our initial attempt at 3-amino-1,2,4-oxadiazole synthesis using models $N$-butyl- $N^{\prime}$ hydroxyguanidine and ethyl phenylacetate (3 equiv) with $\mathrm{NaOEt}$ (2-3 equiv) in EtOH at reflux for $5 \mathrm{~h}$ proceeded in 50-70\% yield based on the hydroxyguanidine. However, the yield dropped to $0-15 \%$ without both excess ester and $\mathrm{NaOEt}$ and the reaction proceeded in only $30 \%$ yield with ethyl indole- 3 -acetate ( 3 equiv) and $\mathrm{NaOEt}$ ( 3 equiv). These initial results indicated that an ester is not sufficiently reactive to couple with a hydroxyguanidine unless it is used in large excess. We therefore chose use an acid chloride rather than an ester to form the 3-amino-1,2,4-oxadiazole, a protocol that has been reported in the recent patent literature. ${ }^{9}$

Indole-3-acetic acid (9b) was reacted with oxalyl chloride and catalytic DMF in $\mathrm{CH}_{2} \mathrm{Cl}_{2}$ to give acid chloride $10 \mathrm{~b}$, which was treated with 1.5 equiv of freshly prepared $\mathbf{8}$ and $\mathrm{Et}_{3} \mathrm{~N}$ in $\mathrm{CH}_{2} \mathrm{Cl}_{2}$ for $2 \mathrm{~h}$ at $25^{\circ} \mathrm{C}$. The solution was concentrated, and a solution of the residue containing the initial coupling product in 1,2 -dichloroethane was heated at $80^{\circ} \mathrm{C}$ for $2 \mathrm{~h}$ to form the 3-amino-1,2,4-oxadiazole giving 11b in 63\% yield from $\mathbf{9 b}$ and $40 \%$ yield from $\mathbf{6}$. The change of solvents after the initial coupling was necessitated by the high temperature needed for ring closure to form the 1,2,4-oxadiazole and the poor solubility of $\mathbf{8}$ and $\mathbf{1 0 b}$ in $\mathrm{ClCH}_{2} \mathrm{CH}_{2} \mathrm{Cl}$.

Reduction of the azide group of $\mathbf{1 1 b}$ was complicated by the sensitivity of the 1,2,4oxadiazole. ${ }^{2}$ Attempted hydrogenation over Pd destroyed the 1,2,4-oxadiazole ring. Reduction with $\mathrm{Ph}_{3} \mathrm{P}$ was successful, but removal of the phosphine oxide byproduct was difficult. Eventually we found that reduction of the azide with activated zinc ${ }^{10}$ and ammonium formate in $\mathrm{MeOH}$ for $7 \mathrm{~h}$ at $25{ }^{\circ} \mathrm{C}$ proceeded cleanly to give polar amine $\mathbf{1 2 b}$ that was used without purification. ${ }^{11 a}$ Coupling of $\mathbf{1 2 b}$ with Boc-protected $S$ methylisothiourea 13 using $\mathrm{Et}_{3} \mathrm{~N}$ and $\mathrm{AgNO}_{3}{ }^{4 \mathrm{~b}, 12}$ in DMF for $2 \mathrm{~h}$ at $0{ }^{\circ} \mathrm{C}$ and $5 \mathrm{~h}$ at $25^{\circ} \mathrm{C}$ afforded protected guanidine $14 \mathrm{~b}$ in $60 \%$ yield from $11 \mathrm{~b}$. Deprotection of $14 \mathrm{~b}$ by stirring in 10:1 $\mathrm{CH}_{2} \mathrm{Cl}_{2} / \mathrm{TFA}$ for $8 \mathrm{~h}$ at $25^{\circ} \mathrm{C}$ removed the Boc protecting groups providing phidianidine $\mathrm{B}(\mathbf{1 b})$ in $92 \%$ yield. The ${ }^{1} \mathrm{H}$ and ${ }^{13} \mathrm{C}$ NMR spectral data of phidianidine $\mathrm{B}$ in both $\mathrm{CD}_{3} \mathrm{OD}$ and DMSO- $d_{6}$ are identical to those reported for the natural product ${ }^{1}$ confirming the presence of the 1,2,4-oxadiazole ring.

Phidianidine A (1a) was prepared by an analogous sequence of steps from 6-bromoindole-3acetic acid (9a).${ }^{13}$ Acid chloride $10 \mathbf{b}$ was coupled with hydroxyguanidine 8 to give 11a in $61 \%$ yield from 9a and 39\% yield from $\mathbf{6}$. Reduction of the azide of 11a with zinc and ammonium formate afforded amine 12a which was coupled with 13 using $\mathrm{Et}_{3} \mathrm{~N}$ and $\mathrm{AgNO}_{3}$ in DMF to give protected guanidine 14a in 61\% yield from 11a. Deprotection of 14a in 10:1 $\mathrm{CH}_{2} \mathrm{Cl}_{2}$ /TFA provided phidianidine $\mathrm{A}(\mathbf{1 a})$ in $93 \%$ yield with ${ }^{1} \mathrm{H}$ and ${ }^{13} \mathrm{C}$ NMR spectral data in both $\mathrm{CD}_{3} \mathrm{OD}$ and DMSO- $d_{6}$ identical to those reported for the natural product. ${ }^{1}$

Initial screening in the NCI 60 cell line screen at $10^{-5} \mathrm{M}$ showed an average of $33 \%$ inhibition of cell growth with phidianidine A (1a). The amine precursor 12a was more potent with an average of $81 \%$ inhibition of the 60 cell lines. Phidianidine B (1b) and amine 12b were both much less effective with an average of 5\% inhibition of cell growth. These results indicate that the bromine substituent on the indole is important for activity and that the amine of 12a is more effective than the guanidine of 1a. Full details for these four compounds with all 60 cell lines are provided in the Supporting Information. 
In conclusion, $N$-5-azido-1-pentanamine (6) was elaborated to $N$-5-azidopentyl- $N^{\prime}$ hydroxyguanidine (8) in two steps. Reaction of 8 with indole-3-acetyl chloride 10a or 10b afforded 3-(5-azidopentylamino)-5-((indol-3-yl)-methyl)-1,2,4-oxadiazoles 11a and 11b in $61-63 \%$ yield. Reduction of the azides with zinc and ammonium formate afforded amines 12a and 12b, which were elaborated to the guanidine, completing short and efficient syntheses of the cytotoxic natural products phidianidines A (1a) and B (1b) in $19 \%$ overall yield by a convergent route that will make analogues readily available for biological evaluation.

\section{Experimental Section}

\section{General Experimental Methods}

Reactions were conducted in flame- or oven-dried glassware under a nitrogen atmosphere and were stirred magnetically. The phrase "concentrated" refers to removal of solvents by means of a rotary-evaporator attached to a diaphragm pump (15-60 Torr) followed by removal of residual solvents at $<1$ Torr with an vacuum pump. Flash chromatography was performed on silica gel 60 (230-400 mesh). Analytical thin layer chromatography (TLC) was performed using silica gel $60 \mathrm{~F}-254$ pre-coated glass plates $(0.25 \mathrm{~mm})$. TLC Plates were analyzed by short wave UV illumination, or by dipping in CAM stain ( $40 \mathrm{~g}$ of ammonium molybdate, $1.6 \mathrm{~g}$ of ceric ammonium molybdate, $80 \mathrm{~mL}$ of concentrated sulfuric acid and $720 \mathrm{~mL}$ of water) and heating on a hot plate, or by spraying with permanganate solution (5 g $\mathrm{KMnO}_{4}$ in $495 \mathrm{~mL}$ water). THF and ether were dried and purified by distillation from sodium/benzophenone. $\mathrm{Et}_{3} \mathrm{~N}$, pyridine, acetonitrile and benzene were distilled from $\mathrm{CaH}_{2} \cdot{ }^{1} \mathrm{H}$ and ${ }^{13} \mathrm{C}$ NMR spectra were obtained on a $400 \mathrm{MHz}$ spectrometer in $\mathrm{CDCl}_{3}$ with tetramethylsilane as internal standard unless specifically indicated. Chemical shifts are reported in $\delta$ ( $\mathrm{ppm}$ downfield from tetramethylsilane). Coupling constants are reported in $\mathrm{Hz}$ with multiplicities denoted as s (singlet), d (doublet), $t$ (triplet), q (quartet), $p$ (pentet), $m$ (multiplet) and br (broad). IR spectra were acquired on an FT-IR spectrometer and are reported in wave numbers $\left(\mathrm{cm}^{-1}\right)$. High resolution mass spectra were obtained using electrospray ionization (ESI) analyzed by quadrupole time of flight (QTof).

5-Azido-1-pentanamine (5) ${ }^{6}$-To a solution of $\mathbf{5}^{6,14}(1.1 \mathrm{~g}, 7.1 \mathrm{mmol})$ in $5 \mathrm{~mL}$ of $\mathrm{Et}_{2} \mathrm{O}$ was added $5 \mathrm{~mL}$ of EtOAc and $9 \mathrm{~mL}$ of $5 \% \mathrm{HCl}$ aqueous solution successively. To the resulting mixture at $0{ }^{\circ} \mathrm{C}$ was added $\mathrm{PPh}_{3}(1.9 \mathrm{~g}, 7.2 \mathrm{mmol}, 1.0$ equiv) in small portions over $1 \mathrm{~h}$. The mixture was stirred at room temperature for $30 \mathrm{~h} .1 \mathrm{M} \mathrm{HCl}$ solution $(10 \mathrm{~mL})$ was added, the layers were separated, and the organic layer was discarded. The aqueous layer was washed with $\mathrm{CH}_{2} \mathrm{Cl}_{2}(20 \mathrm{~mL} \times 2)$, which was discarded, and neutralized with $6 \mathrm{M}$ $\mathrm{NaOH}$ until the $\mathrm{pH}$ reached 12 . The basic aqueous layer was saturated with $\mathrm{NaCl}$ and extracted with $\mathrm{CH}_{2} \mathrm{Cl}_{2}(20 \mathrm{~mL} \times 4)$. The combined organic layers were dried over $\mathrm{Na}_{2} \mathrm{SO}_{4}$ and concentrated to give $780 \mathrm{mg}$ ( $85 \%$ from 5 ) of $\mathbf{6}$ as a colorless oil: ${ }^{1} \mathrm{H}$ NMR $3.28(\mathrm{t}, 2, J$ $=6.8), 2.73$ (t, $2, J=6.8$ ), 2.12 (br, 2, NH $\left.\mathrm{N}_{2}\right), 1.67-1.58(\mathrm{~m}, 2), 1.55-1.45$ (m, 2), 1.48-1.38 (m, 2); ${ }^{13} \mathrm{C}$ NMR 51.3, 41.7, 32.7, 28.6, 24.0; IR (neat) 3318 (br), 2933, 2862, 2089, 1558, $1469,1390,1300,1259$. The spectral data are identical to those previously reported. ${ }^{6}$

N-(5-Azidopentyl)-5-[(1 H-indol-3-yl)methyl]-1,2,4-oxadiazol-3-amine (11b)-To a suspension of $9 \mathbf{b}(350 \mathrm{mg}, 2.0 \mathrm{mmol})$ in $10 \mathrm{~mL}$ of $\mathrm{CH}_{2} \mathrm{Cl}_{2}$ at $0{ }^{\circ} \mathrm{C}$ was added DMF (2 drops) and oxalyl chloride $(0.51 \mathrm{~mL}, 5.9 \mathrm{mmol}, 3.0$ equiv) successively. The mixture was stirred at $0{ }^{\circ} \mathrm{C}$ for $1.5 \mathrm{~h}$ and concentrated to give $450 \mathrm{mg}$ of crude $1 H$-indole-3-acetyl chloride (10b), which was used for the synthesis of $\mathbf{1 1 b}$ without further purification.

To a solution of $6(400 \mathrm{mg}, 3.1 \mathrm{mmol})$ in $6 \mathrm{~mL}$ of $\mathrm{CH}_{2} \mathrm{Cl}_{2}$ was added $\mathrm{NaHCO}_{3}(1.6 \mathrm{~g}, 19$ mmol, 6.0 equiv) and $7 \mathrm{~mL}$ of $\mathrm{H}_{2} \mathrm{O}$ successively. To the resulting mixture was slowly added 
a solution of $\mathrm{BrCN}$ (394 mg, $3.7 \mathrm{mmol}, 1.2$ equiv) in $2 \mathrm{~mL}$ of $\mathrm{CH}_{2} \mathrm{Cl}_{2}$ at $0{ }^{\circ} \mathrm{C}$. The mixture was stirred at $0{ }^{\circ} \mathrm{C}$ for $0.5 \mathrm{~h}$ and at room temperature for $1 \mathrm{~h}$. The reaction was quenched by addition of water $(10 \mathrm{~mL})$. The mixture was extracted with $\mathrm{CH}_{2} \mathrm{Cl}_{2}(15 \mathrm{~mL} \times 3)$. The combined organic layers were dried over $\mathrm{Na}_{2} \mathrm{SO}_{4}$ and concentrated to give $460 \mathrm{mg}(96 \%$ from 6) of $>90 \%$ pure $\mathbf{7}$ as a somewhat unstable pale yellow oil that can be stored for a few days at $0{ }^{\circ} \mathrm{C}:{ }^{1} \mathrm{H}$ NMR $3.73(\mathrm{br}, 1, \mathrm{NH}), 3.31(\mathrm{t}, 2, J=6.8), 3.10(\mathrm{dt}, 2, J=6.8,6.8)$, 1.71-1.59 (m, 4), 1.52-1.42 (m, 2); ${ }^{13}$ C NMR 116.0, 51.1, 46.0, 29.1, 28.3, 23.4; IR (neat) 3211 (br), 2937, 2865, 2215, 2090, 1454, 1351, 1246, 1159.

To a solution of crude 7 ( $460 \mathrm{mg}, 3.0 \mathrm{mmol}$ ) in $10 \mathrm{~mL}$ of dry EtOH was added $\mathrm{NH}_{2} \mathrm{OH} \cdot \mathrm{HCl}$ (252 mg, $3.6 \mathrm{mmol}, 1.2$ equiv) and $\mathrm{K}_{2} \mathrm{CO}_{3}(1.24 \mathrm{~g}, 9.0 \mathrm{mmol}, 3.0$ equiv) successively. The reaction mixture was stirred at room temperature for $5 \mathrm{~h}$, diluted with EtOAc $(20 \mathrm{~mL})$ and filtered through Celite. The filtrate was dried over $\mathrm{Na}_{2} \mathrm{SO}_{4}$ and concentrated to give $502 \mathrm{mg}$ of crude 8 as an unstable pale yellow sticky oil, which decomposed on storage at $0{ }^{\circ} \mathrm{C}$ overnight and should be used immediately in the next step: ${ }^{1} \mathrm{H}$ NMR (DMSO- $\left.d_{6}\right) 9.50$ (br, 1 , $\mathrm{NH}$ or $\mathrm{OH}$ ), 7.49 (br, 1, NH or $\mathrm{OH}), 7.32$ (br, 2, NH or OH), 3.33 (t, $2, J=7.2), 3.14-3.06$ $(\mathrm{m}, 2), 1.60-1.42(\mathrm{~m}, 4), 1.38-1.26(\mathrm{~m}, 2)$.

To a solution of freshly prepared crude $8(502 \mathrm{mg}$, from $400 \mathrm{mg}(3.1 \mathrm{mmol})$ of $\mathbf{6})$ and $\mathrm{NEt}_{3}$ $(0.83 \mathrm{~mL}, 6.0 \mathrm{mmol})$ in $10 \mathrm{~mL}$ of $\mathrm{CH}_{2} \mathrm{Cl}_{2}$ at $0{ }^{\circ} \mathrm{C}$ was added a solution of crude $\mathbf{1 0 b}(450$ $\mathrm{mg}$, from $350 \mathrm{mg}(2.0 \mathrm{mmol})$ of $\mathbf{9 b})$ in $4 \mathrm{~mL}$ of $\mathrm{CH}_{2} \mathrm{Cl}_{2}$. The reaction mixture was stirred at room temperature for $2 \mathrm{~h}$ and concentrated. To the residue was added $15 \mathrm{~mL}$ of $\mathrm{ClCH}_{2} \mathrm{CH}_{2} \mathrm{Cl}$. The mixture was heated at $80{ }^{\circ} \mathrm{C}$ for $2 \mathrm{~h}$ and concentrated. To the residue was added $15 \mathrm{~mL}$ of saturated $\mathrm{NaHCO}_{3}$ solution. The mixture was extracted with $\mathrm{CH}_{2} \mathrm{Cl}_{2}(15$ $\mathrm{mL} \times 4$ ). The combined organic layers were dried over $\mathrm{Na}_{2} \mathrm{SO}_{4}$ and concentrated. Flash chromatography of the residue on silica gel $\left(6: 1 \mathrm{CH}_{2} \mathrm{Cl}_{2} / \mathrm{EtOAc}\right)$ gave $410 \mathrm{mg}$ (63\% from 9b, $40 \%$ from 6) of $\mathbf{1 1 b}$ as a beige solid: $\mathrm{mp} 58-59{ }^{\circ} \mathrm{C} ;{ }^{1} \mathrm{H}$ NMR $8.16(\mathrm{br}, 1, \mathrm{NH}) 7.63(\mathrm{br} \mathrm{d}$, $1, J=8.0$ ), 7.37 (br d, 1, $J=8.0$ ), 7.22 (br dd, $1, J=8.0,8.0$ ), 7.20 (br s, 1), 7.15 (br dd, $1, J$ $=8.0,8.0), 4.29(\mathrm{br}, 1, \mathrm{NH}), 4.22(\mathrm{~s}, 2), 3.25(\mathrm{t}, 2, J=6.8), 3.23(\mathrm{dt}, 2, J=6.8,6.8)$, 1.68-1.56 (m, 4), 1.49-1.37 (m, 2); ${ }^{13} \mathrm{C}$ NMR 177.3, 168.6, 136.1, 126.7, 123.0, 122.5, 119.9, 118.7, 111.3, 108.1, 51.2, 43.1, 28.9, 28.5, 23.9, 23.4; IR (neat) 3306 (br), 2092, $1703,1661,1594,1456,1339,1247,740$; HRMS (ESI) calcd for $\mathrm{C}_{16} \mathrm{H}_{20} \mathrm{~N}_{7} \mathrm{O}\left(\mathrm{MH}^{+}\right)$ 326.1729 , found 326.1727 .

N-(5-Azidopentyl)-5-[(6-bromo-1 H-indol-3-yl)methyl]-1,2,4-oxadiazol-3-amine (11a)-To a suspension of $9 \mathrm{a}(254 \mathrm{mg}, 1.0 \mathrm{mmol})$ in $10 \mathrm{~mL}$ of $\mathrm{CH}_{2} \mathrm{Cl}_{2}$ at $0{ }^{\circ} \mathrm{C}$ was added DMF ( 2 drops) and oxalyl chloride $(0.26 \mathrm{~mL}, 3.0 \mathrm{mmol}, 3.0$ equiv) successively. The mixture was stirred at $0{ }^{\circ} \mathrm{C}$ for $1.5 \mathrm{~h}$ and concentrated to give $320 \mathrm{mg}$ of crude 10a, which was used for the synthesis of 11a without further purification.

To a solution of freshly prepared crude $\mathbf{8}$ (see preparation of $\mathbf{1 1 b}$ for procedure) (254 $\mathrm{mg}$, from $200 \mathrm{mg}(1.6 \mathrm{mmol})$ of $\mathbf{6})$ and $\mathrm{NEt}_{3}(0.42 \mathrm{~mL}, 3.0 \mathrm{mmol})$ in $5 \mathrm{~mL}$ of $\mathrm{CH}_{2} \mathrm{Cl}_{2}$ at $0{ }^{\circ} \mathrm{C}$ was added a solution of crude 10a $(320 \mathrm{mg}$, from $254 \mathrm{mg}(1.0 \mathrm{mmol})$ of $9 \mathbf{a})$ in $2 \mathrm{~mL}$ of $\mathrm{CH}_{2} \mathrm{Cl}_{2}$. The reaction mixture was stirred at room temperature for $2 \mathrm{~h}$ and concentrated. To the residue was added $8 \mathrm{~mL}$ of $\mathrm{ClCH}_{2} \mathrm{CH}_{2} \mathrm{Cl}$. The mixture was heated at $80^{\circ} \mathrm{C}$ for $2 \mathrm{~h}$ and concentrated. To the residue was added $15 \mathrm{~mL}$ of saturated $\mathrm{NaHCO}_{3}$ solution. The mixture was extracted with $\mathrm{CH}_{2} \mathrm{Cl}_{2}(15 \mathrm{~mL} \times 4)$. The combined organic layers were dried over $\mathrm{Na}_{2} \mathrm{SO}_{4}$ and concentrated. Flash chromatography of the residue on silica gel $\left(6: 1 \mathrm{CH}_{2} \mathrm{Cl}_{2} /\right.$ EtOAc) gave $246 \mathrm{mg}$ (61\% from 9a, 39\% from 6) of 11a as a beige solid: $\mathrm{mp} 86-87{ }^{\circ} \mathrm{C} ;{ }^{1} \mathrm{H}$ NMR 8.21 (br, 1, NH) 7.51 (br s, 1), 7.47 (br d, 1, $J=8.4$ ), 7.24 (br d, 1, $J=8.4$ ), 7.16 (br s, 1), 4.29 (br, 1, NH), 4.18 (s, 2), 3.26 (t, 2, $J=6.8$ ), 3.23 (dt, 2, $J=6.8,6.8), 1.68-1.56$ (m, 4), 1.49-1.37 (m, 2); ${ }^{13} \mathrm{C}$ NMR 177.0, 168.6, 136.9, 125.6, 123.7, 123.2, 120.0, 116.1, 114.2, 
108.3, 51.2, 43.1, 28.9, 28.5, 23.9, 23.3; IR (neat) 3296 (br), 2092, 1594, 1453, 1330, 1236, 893, 803, 735; HRMS (ESI) calcd for $\mathrm{C}_{16} \mathrm{H}_{19} \mathrm{BrN}_{7} \mathrm{O}\left(\mathrm{MH}^{+}\right) 404.0834$, found 404.0833 .

$\mathrm{N}$-[5-[[Bis[[(1,1-dimethylethoxy)carbonyl]amino]methylene]amino]pentyl]-5[(1 H-indol-3-yl)methyl]-1,2,4-oxadiazol-3-amine (14b)-To a solution of $\mathbf{1 1 b}$ (410 $\mathrm{mg}, 1.26 \mathrm{mmol})$ in $8 \mathrm{~mL}$ of $\mathrm{MeOH}$ was added ammonium formate $(397 \mathrm{mg}, 6.30 \mathrm{mmol}, 5.0$ equiv) and activated zinc ${ }^{10}(328 \mathrm{mg}, 5.04 \mathrm{mmol}, 4.0$ equiv) successively. The mixture was stirred at room temperature for $7 \mathrm{~h}$. The reaction was quenched by addition of $1 \mathrm{M} \mathrm{NaOH}$ $(15 \mathrm{~mL})$. The mixture was extracted with $\mathrm{CH}_{2} \mathrm{Cl}_{2}(15 \mathrm{~mL} \times 4)$. The combined organic layers were dried over $\mathrm{Na}_{2} \mathrm{SO}_{4}$ and concentrated to give $390 \mathrm{mg}$ of crude $\mathbf{1 2 b}$, which was used in the next step without purification: ${ }^{1} \mathrm{H}$ NMR 8.14 (br, 1, NH), 7.63 (br d, 1, J= 8.0), 7.38 (br d, 1, $J=8.0$ ), 7.22 (br dd, 1, $J=8.0,8.0$ ), 7.22 (br s, 1), 7.15 (br dd, 1, $J=8.0,8.0$ ), 4.26 (br, 1, NH), 4.22 (s, 2), 3.23 (dt, 2, $J=6.8,6.8$ ), 2.68 (t, 2, $J=6.8$ ), 1.68-1.54 (m, 2), 1.52-1.32 $(\mathrm{m}, 4)$.

To a solution of crude $\mathbf{1 2 b}(390 \mathrm{mg})$ in $8 \mathrm{~mL}$ of DMF was added 1,3-bis (tertbutoxycarbonyl)-2-methylthiopseudourea (13) $(561 \mathrm{mg}, 1.89 \mathrm{mmol})$ and $\mathrm{NEt}_{3}(1.40 \mathrm{~mL}$, $10.1 \mathrm{mmol}$ ) successively. To the resulting mixture at $0{ }^{\circ} \mathrm{C}$ was added $\mathrm{AgNO}_{3}(429 \mathrm{mg}, 2.52$ mmol) in small portions. The reaction was stirred at $0{ }^{\circ} \mathrm{C}$ for $2 \mathrm{~h}$ and at room temperature for $5 \mathrm{~h}$. The reaction was quenched by addition of EtOAc $(50 \mathrm{~mL})$ and filtered through Celite. The filtrate was washed with saturated $\mathrm{NaHCO}_{3}(50 \mathrm{~mL} \times 4)$, dried over $\mathrm{Na}_{2} \mathrm{SO}_{4}$, and concentrated. Flash chromatography of the residue on silica gel (2:3 EtOAc/hexanes) gave $417 \mathrm{mg}$ (61\% from 11b) of 14b as a pale yellow sticky oil: ${ }^{1} \mathrm{H}$ NMR 11.49 (br s, 1, NH), 8.30 (br, 2, NH), 7.62 (br d, 1, $J=8.0$ ), 7.37 (br d, 1, $J=8.0$ ), 7.21 (br dd, 1, $J=8.0,8.0$ ), 7.20 (br s, 1), 7.14 (br dd, 1, $J=8.0,8.0$ ), 4.33 (br, 1, NH), 4.22 (s, 2), 3.37 (dt, 2, $J=6.8$, 6.8), 3.20 (dt, $2, J=6.8,6.8), 1.64-1.54(\mathrm{~m}, 4), 1.50(\mathrm{~s}, 9), 1.49(\mathrm{~s}, 9), 1.42-1.32(\mathrm{~m}, 2) ;{ }^{13} \mathrm{C}$ NMR 177.2, 168.7, 163.6, 156.1, 153.3, 136.1, 126.7, 123.0, 122.3, 119.8, 118.7, 111.3, 108.0, 83.1, 79.3, 43.1, 40.7, 29.0, 28.6, 28.3 (3 C), 28.0 (3 C), 24.0, 23.4; IR (neat) 3324 (br), 1719, 1597, 1414, 1366, 1325, 1129, 1053, 912, 731; HRMS (ESI) calcd for $\mathrm{C}_{27} \mathrm{H}_{40} \mathrm{~N}_{7} \mathrm{O}_{5}\left(\mathrm{MH}^{+}\right)$542.3091, found 542.3085.

\section{$N$-[5-[[Bis[[(1,1-dimethylethoxy)carbonyl]amino]methylene]amino]pentyl]-5-} [(6-bromo-1 $\boldsymbol{H}$-indol-3-yl)methyl]-1,2,4-oxadiazol-3-amine (14a)-To a solution of $11 \mathrm{a}(246 \mathrm{mg}, 0.61 \mathrm{mmol})$ in $5 \mathrm{~mL}$ of $\mathrm{MeOH}$ was added ammonium formate (192 $\mathrm{mg}, 3.05$ mmol, 5.0 equiv) and activated zinc ${ }^{10}(159 \mathrm{mg}, 2.44 \mathrm{mmol}, 4.0$ equiv) successively. The mixture was stirred at room temperature for $7 \mathrm{~h}$. The reaction was quenched by addition of 1 $\mathrm{M} \mathrm{NaOH}(15 \mathrm{~mL})$. The mixture was extracted with $\mathrm{CH}_{2} \mathrm{Cl}_{2}(15 \mathrm{~mL} \times 4)$. The combined organic layers were dried over $\mathrm{Na}_{2} \mathrm{SO}_{4}$ and concentrated to give $228 \mathrm{mg}$ of crude 12a, which was used in the next step without purification: ${ }^{1} \mathrm{H}$ NMR $8.15(\mathrm{br}, 1, \mathrm{NH}) 7.53$ (br s, 1), 7.48 (br d, 1, $J=8.4$ ), 7.24 (br d, 1, $J=8.4$ ), 7.19 (br s, 1), 4.29 (br, 1, NH), 4.18 (s, 2), $3.23(\mathrm{dt}, 2, J=6.8,6.8), 2.68(\mathrm{t}, 2, J=6.8), 1.68-1.54(\mathrm{~m}, 2), 1.52-1.32(\mathrm{~m}, 4)$.

To a solution of crude 12a (228 mg) in $4 \mathrm{~mL}$ of DMF was added 1,3-bis (tertbutoxycarbonyl)-2-methylthiopseudourea (13) $(267 \mathrm{mg}, 0.92 \mathrm{mmol})$ and $\mathrm{NEt}_{3}(0.70 \mathrm{~mL}$, $5.06 \mathrm{mmol})$ successively. To the resulting mixture at $0{ }^{\circ} \mathrm{C}$ was added $\mathrm{AgNO}_{3}(207 \mathrm{mg}, 1.22$ $\mathrm{mmol}$ ) in small portions. The reaction was stirred at $0{ }^{\circ} \mathrm{C}$ for $2 \mathrm{~h}$ and at room temperature for $5 \mathrm{~h}$. The reaction was quenched by addition of EtOAc $(30 \mathrm{~mL})$ and filtered through Celite. The filtrate was washed with saturated $\mathrm{NaHCO}_{3}(30 \mathrm{~mL} \times 4)$, dried over $\mathrm{Na}_{2} \mathrm{SO}_{4}$, and concentrated. Flash chromatography of the residue on silica gel (2:3 EtOAc/hexanes) gave $226 \mathrm{mg}$ ( $60 \%$ from 11a) of 14a as a pale yellow sticky oil: ${ }^{1} \mathrm{H}$ NMR 11.50 (br s, 1, NH), 8.70 (br, 1, NH), 8.31 (br, 1, NH), 7.52 (br s, 1), 7.47 (br d, 1, $J=8.0$ ), 7.23 (br d, 1, $J=8.0$ ), 7.16 (br s, 1), 4.47 (br, 1, NH), 4.18 (s, 2), 3.32 (dt, 2, $J=6.8,6.8$ ), 3.16 (dt, 2, $J=6.8,6.8$ ), 1.58-1.46 (m, 4), 1.49 (s, 18), 1.34-1.24 (m, 2); ${ }^{13} \mathrm{C}$ NMR 176.9, 168.7, 163.5, 156.1, 153.3, 
136.9, 125.7, 123.7, 123.1, 120.0, 115.9, 114.3, 108.2, 83.1, 79.4, 43.1, 40.7, 29.0, 28.6, 28.3 (3 C), 28.0 (3 C), 24.0, 23.3; IR (neat) 3322 (br), 1718, 1598, 1413, 1366, 1330, 1131, 1052, 910, 803, 730; HRMS (ESI) calcd for $\mathrm{C}_{27} \mathrm{H}_{39} \mathrm{BrN}_{7} \mathrm{O}_{5}\left(\mathrm{MH}^{+}\right)$620.2196, found 620.2187.

$N$-[5-[(Aminoiminomethyl)amino]pentyl]-5-[(1H-indol-3-yl)methyl]-1,2,4oxadiazol-3-amine Trifluoroacetic Acid Salt (Phidianidine B, 1b)-14b (417 mg, $0.77 \mathrm{mmol}$ ) was taken up in $20 \mathrm{~mL}$ of $1: 10 \mathrm{TFA} / \mathrm{CH}_{2} \mathrm{Cl}_{2}$, and the resulting solution was stirred at room temperature for $8 \mathrm{~h}$. The mixture was diluted with $25 \mathrm{~mL} \mathrm{MeOH}$ and concentrated to give $326 \mathrm{mg}(93 \%)$ of $>95 \%$ pure $\mathbf{1 b}$ as a pale yellow oil: ${ }^{1} \mathrm{H}$ NMR $\left(\mathrm{CD}_{3} \mathrm{OD}\right) 7.52$ (br d, $1, J=8.0$ ), 7.35 (br d, 1, $J=8.0$ ), 7.21 (br s, 1), 7.11 (br dd, 1, $J=8.0$, 8.0), 7.01 (br dd, 1, $J=8.0,8.0$ ), 4.22 (s, 2), 3.15 (t, 2, $J=6.8$ ), 3.14 (t, 2, $J=6.8$ ), 1.68-1.54 (m, 4), 1.46-1.36 (m, 2); (DMSO- $\left.d_{6}\right) 11.04$ (br s, NH), 7.55 (br t, 1, $J=5.6, \mathrm{NH}$ ), 7.51 (br d, $1, J=8.0$ ), 7.37 (br d, 1, $J=8.0$ ), 7.31 (br d, 1, $J=2.2$ ), 7.09 (br dd, 1, $J=8.0,8.0$ ), 6.99 (br dd, 1, $J=8.0,8.0$ ), 6.72 (br t, 1, $J=5.6, \mathrm{NH}$ ), 4.20 (s, 2), 3.06 (dt, 2, $J=5.6,5.6), 3.01$ (dt, $2, J=5.6,5.6), 1.56-1.40(\mathrm{~m}, 4), 1.35-1.25(\mathrm{~m}, 2) ;{ }^{13} \mathrm{C}$ NMR $\left(\mathrm{CD}_{3} \mathrm{OD}\right.$, referenced to the residual solvent peaks centered at $\delta 49.15)(179.5,170.2,158.8,138.2,128.3,124.8,122.9$, $120.2,119.4,112.5,108.3,43.9,42.5,29.9,29.7,25.0,24.2$; (DMSO- $d_{6}$, referenced to the residual solvent peaks centered at $\delta 39.51) 176.9,168.5,156.7,136.2,126.7,124.2,121.2$, 118.7, 118.4, 111.5, 106.9, 42.3, 40.7, 28.1 (2 C), 23.4, 22.7; IR 3303 (br), 1671, 1599, 1201, 1137; HRMS (ESI) calcd for $\mathrm{C}_{17} \mathrm{H}_{24} \mathrm{~N}_{7} \mathrm{O}\left(\mathrm{M}^{+}\right) 342.2042$, found 342.2047. In both solvents, the indole carbons near the nitrogen are doubled in various ratios due to the presence of both $\mathrm{NH}$ and ND forms of the indole. ${ }^{15}$

\section{$\mathrm{N}$-[5-[(Aminoiminomethyl)amino]pentyl]-5-[(6-bromo-1 H-indol-3- yl)methyl]-1,2,4-oxadiazol-3-amine Trifluoroacetic Acid Salt (Phidianidine A,} 1a)-14a (100 mg, $0.16 \mathrm{mmol}$ ) was taken up in $5 \mathrm{~mL}$ of $1: 10 \mathrm{TFA} / \mathrm{CH}_{2} \mathrm{Cl}_{2}$, and the resulting solution was stirred at room temperature for $8 \mathrm{~h}$. The mixture was diluted with 5 $\mathrm{mL} \mathrm{MeOH}$ and concentrated to give $79 \mathrm{mg}(92 \%)$ of $>95 \%$ pure 1a as a pale yellow oil: ${ }^{1} \mathrm{H}$ NMR $\left(\mathrm{CD}_{3} \mathrm{OD}\right) 7.52$ (br d, 1, $J=1.7$ ), 7.45 (br d, 1, $J=8.0$ ), 7.23 (br s, 1), 7.13 (br dd, $1, J$ $=8.0,1.7), 4.20(\mathrm{~s}, 2), 3.15$ (br t, $4, J=7.2), 1.66-1.54(\mathrm{~m}, 6), 1.46-1.36(\mathrm{~m}, 2) ;\left(\right.$ DMSO- $\left.d_{6}\right)$ 11.18 (br, s, NH), 7.56 (br d, 1, $J=1.7$ ), 7.49 (br s, NH), 7.47 (br d, 1, $J=8.4$ ), 7.35 (br d, 1, $J=2.5$ ), 7.14 (br dd, $1, J=8.4,1.7$ ), 6.73 (br t, $1, J=6.0, \mathrm{NH}$ ), 4.20 (s, 2), 3.06 (dt, $2, J=$ $6.0,6.0), 3.00(\mathrm{dt}, 2, J=6.0,6.0), 1.56-1.42(\mathrm{~m}, 4), 1.34-1.22(\mathrm{~m}, 2) ;{ }^{13} \mathrm{C} \mathrm{NMR}\left(\mathrm{CD}_{3} \mathrm{OD}\right.$, referenced to the residual solvent peaks centered at $\delta 49.15) 179.1,170.3,158.8,139.1$, 127.3, 125.9, 123.4, 121.0, 116.3, 115.5, 108.8, 43.9, 42.5, 29.9, 29.7, 25.1, 24.1; (DMSO$d_{6}$, referenced to the residual solvent peaks centered at $\left.\delta 39.51\right) 176.7,168.5,156.7,137.0$, 125.8, 125.3, 121.6, 120.2, 114.2, 114.0, 107.4, 42.3, 40.7, 28.1 (2 C), 23.3, 22.5; IR 3280 (br), 1670, 1601, 1184, 1137; HRMS (ESI) calcd for $\mathrm{C}_{17} \mathrm{H}_{23} \mathrm{BrN}_{7} \mathrm{O}\left(\mathrm{M}^{+}\right) 420.1147$, found 420.1135. In both solvents, the indole carbons near the nitrogen are doubled in various ratios due to the presence of both $\mathrm{NH}$ and ND forms of the indole. ${ }^{15}$

\section{Supplementary Material}

Refer to Web version on PubMed Central for supplementary material.

\section{Acknowledgments}

We are grateful to the National Institutes of Health (GM-50151) for support of this work. 


\section{References and Notes}

1. Carbone M, Li Y, Irace C, Mollo E, Castelluccio F, Di Pascale A, Cimino G, Santamaria R, Guo YW, Gavagnin M. Org Lett. 2011; 13:2516-2519. [PubMed: 21506595]

2. For reviews of 1,2,4-oxadiazoles, see: Hemming K. J Chem Res, Synop. 2001:209-216.Kayukova LA. Pharm Chem J. 2005; 39:539-547.Pace A, Pierro P. Org Biomol Chem. 2009; 7:4337-4348. [PubMed: 19830279]

3. (a) Byrde RJW, Clifford DR, Woodcock D. Ann Appl Biol. 1962; 50:291-298.(b) Srivastava SK, Smith TA. Phytochemistry. 1981; 21:997-1008.(c) Cabral JPS. Antimicrob Agents Chemother. 1991; 35:341-344. [PubMed: 1902648]

4. (a) Yu M, Pochapsky SS, Snider BB. J Org Chem. 2008; 73:9065-9074. [PubMed: 18928319] (b) Yu M, Snider BB. Org Lett. 2009; 11:1031-1032. [PubMed: 19166346] (c) Yu M, Pochapsky SS, Snider BB. Org Lett. 2010; 12:828-831. [PubMed: 20078082] (d) Barykina OV, Snider BB. Org Lett. 2010; 12:2664-2667. [PubMed: 20446668]

5. (a) Saunders J, MacLeod AM, Merchant K, Showell GA, Snow RJ, Street LJ, Baker R. J Chem Soc, Chem Commun. 1988:1618-1619.(b) Saunders J, Cassidy M, Freedman SB, Harley EA, Iversen LL, Kneen C, MacLeod AM, Merchant KJ, Snow RJ, Baker R. J Med Chem. 1990; 33:1128-1138. [PubMed: 2319559] (c) Street LJ, Baker R, Book T, Kneen CO, MacLeod AM, Merchant KJ, Showell GA, Saunders J, Herbert RH, Freedman SB, Harley EA. J Med Chem. 1990; 33:26902697. [PubMed: 2213823] (d) Showell GA, Gibbons TL, Kneen CO, MacLeod AM, Merchant K, Saunders J, Freedman SB, Patel S, Baker R. J Med Chem. 1991; 34:1086-1094. [PubMed: 2002451] (e) Chen, C-y; Senanayake, CH.; Bill, TJ.; Larsen, RD.; Verhoeven, TR.; Erider, PJ. J Org Chem. 1994; 59:3738-3741.(f) Ahmad S, Ngu K, Combs DW, Wu SC, Weinstein DS, Liu W, Chen B-C, Chandrasena G, Dorso CR, Kirby M, Atwal KS. Bioorg Med Chem Lett. 2004; 14:177180. [PubMed: 14684323] (g) Vieira E, Huwyler J, Jolidon S, Knoflach F, Mutel V, Wichmann J. Bioorg Med Chem Lett. 2005; 15:4628-4631. [PubMed: 16099654]

6. (a) Lee JW, Jun SI, Kim K. Tetrahedron Lett. 2001; 42:2709-2711.(b) Srinivasan R, Tan LP, Wu H, Yang PY, Kalesh KA, Yao SQ. Org Biomol Chem. 2009; 7:1821-1828. [PubMed: 19590777]

7. (a) Snider BB, O'Hare SM. Tetrahedron Lett. 2001; 42:2455-2458.(b) Kumar V, Kaushik MP, Mazumdar A. Eur J Org Chem. 2008:1910-1916.(c) Sathe M, Karade HN, Kaushik MP. Synth Commun. 2008; 38:1375-1380.

8. (a) Pufahl RA, Nanjappan PG, Woodard RW, Marletta MA. Biochemistry. 1992; 31:6822-6828. [PubMed: 1379071] (b) Xian M, Fujiawara N, Wen Z, Cai T, Kazuma S, Janczuk AJ, Tang X, Telyatnikov VV, Zhang Y, Chen X, Miyamoto Y, Taniguchi N, Wang PG. Bioorg Med Lett. 2002; 10:3049-3055.(c) Cho JY, Dutton A, Miller T, Houk KN, Fukuto JM. Arch Biochem Biophys. 2003; 417:65-76. [PubMed: 12921781] (d) Schade D, Kotthaus J, Klein N, Kotthaus J, Clement B. Org Biomol Chem. 2011; 9:5249-5259. [PubMed: 21625725]

9. (a) Cai, SX.; Zhang, H-z; Kuemmerle, JD.; Zhang, H.; Kemnitzer, WE. PCT Int Appl. WO 2004058253 A1. 2004. Chem Abstr. 2004; 141:123632.(b) Fox, BM.; Iio, K.; Inaba, T.; Kayser, F.; Li, K.; Sagawa, S.; Tanaka, M.; Yoshida, A. PCT Int Appl. WO 2005013907 A2. 2005. Chem Abstr. 2005; 142:240441.(c) Kubota, H.; Nakamura, Y.; Higashijima, T.; Yamamoto, Y.; Oka, K.; Igarashi, S. US Pat Appl Publ. US 20070032485 A1. 2007. Chem Abstr. 2007; 146:229322.(d) Kubota, H.; Sugahara, M.; Furukawa, M.; Takano, M.; Motomura, D. US Pat Appl Publ. US 20070082896 A1. 2007. Chem Abstr. 2007; 146:421853.(e) Lachance, N.; Li, CS.; Leclerc, J-P.; Ramtohul, YK. PCT Int Appl. WO 2008064474 A1. 2008. Chem Abstr. 2008; 149:32315.(f) Bradbury, RH.; Hales, NJ.; Rabow, AA. PCT Int Appl. WO 2009081197 A1. 2009. Chem Abstr. 2009; 151:124013.(g) Li, X.; Liu, X.; Loren, J.; Molteni, V.; Nabakka, J.; Yeh, V.; Chianelli, D. PCT Int Appl. WO 2009105712 A1. 2009. Chem Abstr. 2009; 151:313557.(h) Bertram, LS.; Fyfe, MCT.; Gattrell, W.; Jeevaratnam, RP.; Keily, J.; Procter, M. J PCT Int Appl. WO 2010004348 A1. 2010. Chem Abstr. 2010; 152:144685.(i) Fox BM, Iio K, Li K, Choi R, Inaba T, Jackson S, Sagawa S, Shan B, Tanaka M, Yoshida A, Kayser F. Bioorg Med Chem Lett. 2010; 20:6030-6033. [PubMed: 20833038]

10. Hannick SM, Kishi Y. J Org Chem. 1983; 48:3833-3835.

11. (a) Srinivasa GR, Nalina L, Abiraj K, Gowda DC. J Chem Res, Synop. 2003:630-631.(b) Boruah A, Baruah M, Prajapati D, Sandhu JS. Synlett. 1997:1253-1253.(c) Lin W, Zhang X, He Z, Jin Y, 
Gong L, Mi A. Synth Commun. 2002; 32:3279-3284.(d) Amantini D, Fringuelli F, Pizzo F, Vaccaro L. Org Prep Proced Int. 2002; 34:109-147.

12. (a) Ma D, Xia C, Jiang J, Zhang J. Org Lett. 2001; 3:2189-2191. [PubMed: 11440576] (b) Han S, Moore RA, Viola RE. Bioorg Chem. 2002; 30:81-94. [PubMed: 12020133] (c) DeMong DE, Williams RM. J Am Chem Soc. 2003; 125:8561-8565. [PubMed: 12848564]

13. (a) Rasmussen T, Jensen J, Anthoni U, Christophersen C, Nielsen PH. J Nat Prod. 1993; 56:15531558.(b) Baran PS, Shenvi RA. J Am Chem Soc. 2006; 128:14028-14029. [PubMed: 17061876]

14. Thomas JR, Liu X, Hergenrother PJ. J Am Chem Soc. 2005; 127:12434-12435. [PubMed: 16144359]

15. (a) Morales-Ríos MS, Del Río RE, Joseph-Nathan P. Magn Reson Chem. 1988; 26:552-558.(b) Joseph-Nathan P, Del Río RE, Morales-Ríos MS. Heterocycles. 1988; 27:377-383. 
<smiles>[X]c1ccc2c(Cc3nc(NCCCCCNC(N)=[NH2+])no3)c[nH]c2c1</smiles>

1a, $X=B r$ (phidianidine $A$ )

1b, $X=H$ (phidianidine $B$ )
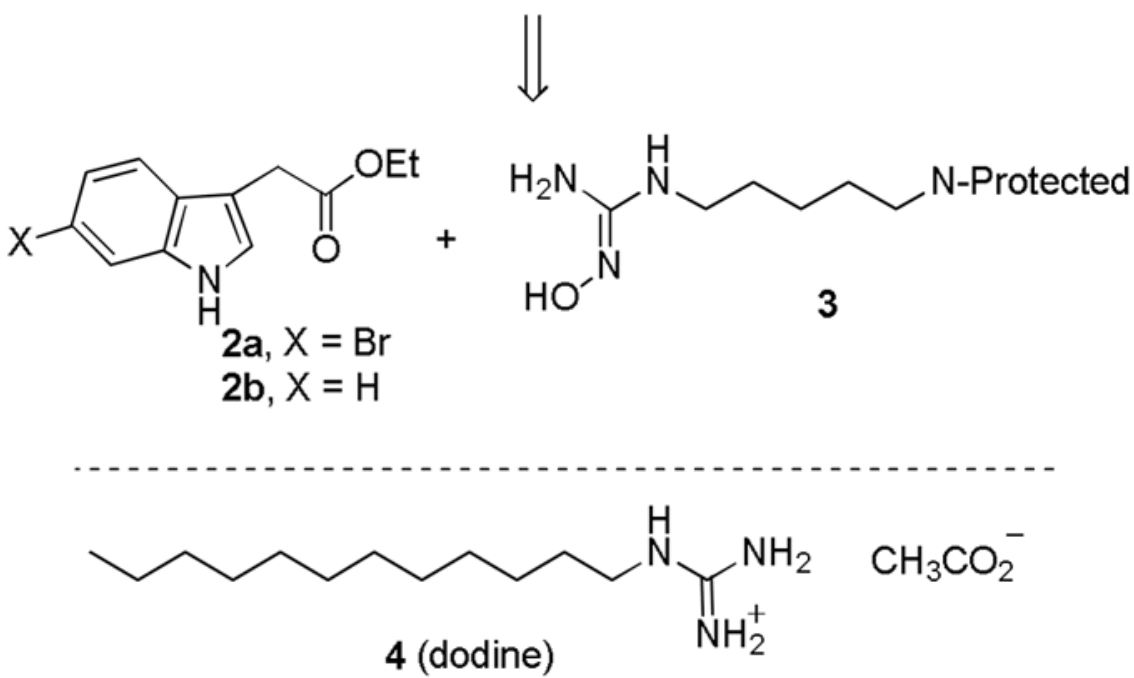

Scheme 1.

Retrosynthesis of Phidianidines A (1a) and B (1b) 


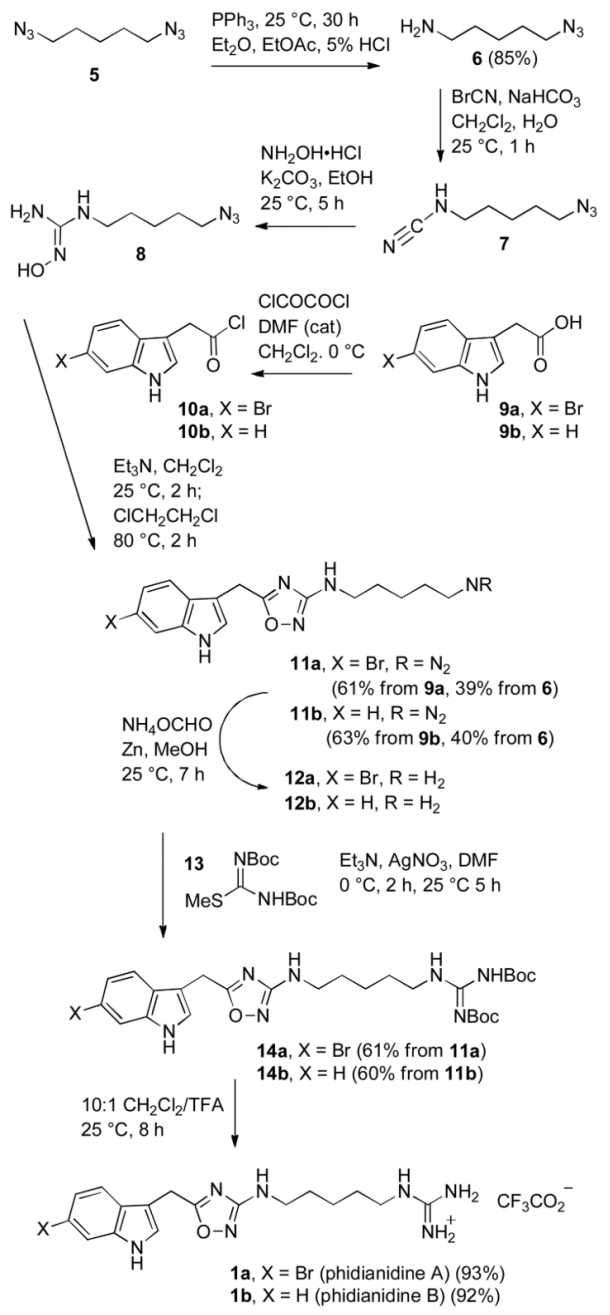

Scheme 2.

Synthesis of Phidianidines A (1a) and B (1b) 